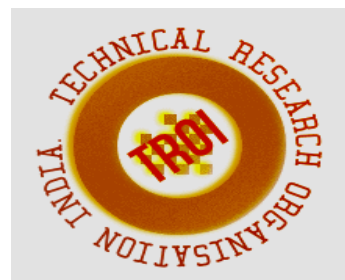

\title{
IMPACT OF SOCIAL-CULTURAL FACTORS ON ENTREPRENEURS IN INDIA
}

\author{
Ankita Barik ${ }^{1}$, Bhavesh Vanparia ${ }^{2}$, Lal Bihari Barik ${ }^{3}$ \\ ${ }^{1}$ Research Scholar, Faculty of Management, Pacific Academy of Higher Education \& Research \\ University, Rajasthan, India \\ ${ }^{2}$ Asst. Prof., MHRD, Veer Narmad South Gujarat University, Surat, Gujarat, India \\ ${ }^{3}$ Asst. Prof., Department of Information Systems, Faculty of Computing \& Information Technology \\ in Rabigh, King Abdulaziz University, Kingdom of Saudi Arabia
}

\begin{abstract}
Society and cultural background of a person plays a vital role in the life of entrepreneurs. Entrepreneurs start ventures, and when they grow, society and economy of a country also grow accordingly. Entrepreneurial education is also important for the entrepreneurs and his/her behavior. Friends, family, and peers also give moral and financial support to the entrepreneur which help him to take a risk and implement new ideas. The main thing to study is how social-cultural factors affect the behavior of entrepreneur or want to be an entrepreneur. This paper focuses on the social and cultural factors like religion, family, financial status, education, and ethics which affect the person who is an entrepreneur or want to be an entrepreneur. In this paper researchers have also analyzed the role of family, peer persons, education to develop the entrepreneur behavior.

Index Terms: Entrepreneurship, Entrepreneurs, Social-Cultural Factors, Venture, Behavior
\end{abstract}

\section{INTRODUCTION}

For the growth of the Indian economy, entrepreneurship is a major factor. If we look at the world, then the rise of the US economy, the condition of Germany after the world war, Israel as a developed economy, all this possible because of the entrepreneurship and entrepreneur of the individual country. As we all know India is a country who is having the world's largest youth and this key factor which will help to take Indian economy to the next level.

An entrepreneur is one person who is willingly ready to take the risk, find the opportunities from the problems, and general job pool-emplacement for the people of the society where he lives. Entrepreneurship is considered to be an engine of economic development. The entrepreneurial process begins with the development of entrepreneurial intentions [1]. Supportive culture can be the reason for social justice, from which entrepreneurial career is becoming more valuable and socially recognized in that culture, so creating a favorable institutional environment [2]. The literature suggests that the formation of different cultural values in different societies influences the decision to create new businesses [3].

Entrepreneurship is all about people who search and evaluate opportunities. It provides individuals to enjoy

Self-Employment, economic development, innovation, employment generation and social development. Entrepreneurship is a vigorous process for the development of nations and regions; it has now become a center of priority for the socio-economic development of the nations.

Humans are primarily social creatures, which have created social structures throughout history, 
which shape their conversation. There are many expressions in these structures which are overlapping many times, for example, state, family, and firms although the family represents a primary institution which affects the composition, existence, and success of enterprises around the world.

Social capital means the networks of relationships among people who live and work in a particular society, enabling that society to function effectively. Parents often assist younger generation family entrepreneurs by using their connections. Through the introduction of young, nascent entrepreneurs into family members' existing social networks, family social capital facilitates the mobilization of other resources and the implementation of funding activities needed for a successful start-up.

By exploiting the previously established relationships between family members and resources holders, family involvement may be instrumental in the acquisition of debt financing, a critical start-up activity (Chua et al., 2011). Children may also access the social capital of parents entrepreneurs, including contacts with suppliers, business partners, and customers, to facilitate the completion of other start-up activities (Laspita et al., 2012; Linda E., Tatiana S., Galina S., Tatyana T., 2016). Social networks are such relationships through which opportunities to use financial and human capital - such relationships in which ownership is not ultimately the property of any individual, but is organized jointly by members of a network [4].

Culture is support through which a person can shape the collectivities in society with its behavior. It is a source of specialty in a business enterprise; it provides assistance in dealing with issues that appear to the entrepreneurs every day on a daily basis. In the socio-cultural environment, all elements, situations, and effects, which shape the personality of an individual and potentially influence his attitude, behavior, judgment, and actions. Such elements are included in the form of beliefs, values, behaviors, habits, behaviors, and lifestyle of persons developed from cultural, religious, educational and social conditioning ( Bennett and Kassarjian, 1972; Adeleke et. al, 2003) [18].

So, this paper aims to link, from a theoretical perspective, the socio-cultural factors and how it affects entrepreneurial behavior. In this sense, the paper states that the institutional approach can be an important framework to develop research in the future, which analyzes socio-cultural factors that influence the decision to do new business.

\section{LITERATURE REVIEW}

Lüthje et al. (2003) survey provide evidence that the perceived contextual barriers and support play a significant role in the entrepreneurial behavior of professional students. Public policy and Universities would be well advised to intensify their activities to implement educational, research and resource programs on entrepreneurship. They also indicate that the conviction to start up a new venture is to some extent a question of personality structure [6].

There are only two entrepreneurial qualities (the inner point of innovation and control) and only one of the many relevant factors (culture), which can help to understand the difference between countries in the rate of new venture formation [6].

Educational institutions and teachers will have to spark the interest in their students towards becoming an entrepreneur. They can provide personality-profiling of students to identify potential entrepreneurs at the school and college level. Parents can play a vital role in the development of young people of their children, entrepreneurial qualities [7].

Hayton et al. (2002), in their paper review, that for the first stream, on the impact of national culture, the total measures of national entrepreneurship such as innovative national output or new business were focused. The second stream addresses the cooperation between the characteristics of national culture and individual entrepreneurs. The third section examines the impact of national culture on corporate entrepreneurship [8].

Linda et al. (2016) findings indicate family social capital positively linked with a range of the initial activities. Family financial capital negatively related to the scope of the initial activities. Family coordination enhances the effectiveness of the social capital of the family on the initial activities [12].

Peter et al. (2014) studies indicate that family firms are less entrepreneurial, on average, especially after the founder departs. There are notable exceptions, however, and so they build a 
new theory to explain how these exceptional firms accomplish transgenerational entrepreneurship [10].

Galina et al. (2015) study focused on two environmental characteristics that may affect the intention-behavior link in student entrepreneurship: the University entrepreneurial environment and perceived level of uncertainty avoidance in the society. The objectives of enterprise lie on the foundation of the entrepreneurial process, yet available evidence points out that the intention of every entrepreneur is ultimately turning to real behavior - starting and operating a new venture [11].

Work experience has been recognized as an essential medium in achieving the behavior and abilities. Work experience can also help the person to provide a unique knowledge and reputation to the organization [13].

Carter (1999) in his study supports the view that a child learns about occupations through examples of the parents as they visit their parents' workplaces. If the impression here is good, then the child seeks to identify with the profession, but if they are bad, the child rejects such profession. Caplow (1994) and Wert (1997) in their separate studies found that career choice is inherited obviously and directly from parents. Furthermore, Miller (2000) in his study discovered that parental attitude and behavior are positively associated with students' career maturity [ 9].

\section{IMPORTANCE OF THE STUDY}

This study analyzes what the role of culture in the development of entrepreneur and its interest is. Factors like Family, their expectations, influences of peers and friends play a vital role in the behavior of the entrepreneur. On the other hand, entrepreneur's education plays a major role in the self-confidence building and choosing the entrepreneur as a career. Keeping in mind about how cultural factor affect entrepreneur behavior, researchers have to try to focus on the cultural as a construct for this study.

1. Culture plays an important role in the behavior of entrepreneur.

2. Family business and entrepreneurship as career both are connected with each other
3. Friends and peers influence the behavior of Entrepreneur.

4. There is an impact of education on the development of Entrepreneurial

\section{RESEARCH METHODOLOGY}

The present study on populations comprised of all ventures that were enrolled with Food Safety and Standards Authority of India (FSSAI 2006) under the Food Safety and Standards Act, 2006. The researchers decided to choose this universe because of the reason that Surat city is the fourth fastest growing city in the world and has its rich social-cultural background.

For the past seven facial years, the economic discrepancy in this entrepreneurship has a moderately diverse composition with various parts of entrepreneurs like Textile, Diamond Cutting \& Polishing, Export and Food Industries with the annual GDP growth rate of $11.5 \%$ in Surat city.

Besides, the universe made out of various urban zones with practically same social-cultural patterns that can be overlooked while defining speculation in light of the present study. Researchers have used convenient sampling technique as this study is entirely different in nature and also keep in mind the entrepreneur's availability. Researchers have taken a sample of four respondents which were accessible with Food Safety and Standards Authority of (INDIA). Researchers conduct appointments using the phone to settle a time for an interview. For the purpose of data collection, a meeting aid was prepared. Researchers have used face to face interview methods for the collection of information in this study. With the end goal of exactness, researchers have recorded all the conversations over Mobile. Later on, this conversation of regional Gujarati language was translated into the English language.

As this research is qualitative in nature, researchers have used critical analysis technique; to study how individual get influence through the culture and society. For this, researchers have kept the proof taken from the literature. 
V. ANALYSIS OF THE INTERVIEWS

A. Privately-owned family business \& Entrepreneurial conduct.

Mr. Jai Prakash had a solid effect on family in creating is entrepreneurial conduct. His sibling is running a general store. He used to help his sibling in a shop in the wake of returning from school. So he got much involvement in the treatment of business. Later on, he began doing compost business. He began promoting of composts on his own.

In the case of Mr. Jai Prakash, has the more grounded effect of family on his entrepreneurial conduct. His dad was a specialist, and he had bakery shop while his sibling began a similar business in Bardoli and picked up involvement in pastry kitchen and worked a couple of years, which eventually provoked him to begin another venture in Bardoli. His family bolstered him ethically and financially to launch a new business, particularly his sibling helped him a great deal in a start-up with his experience.

\section{B. Peer gathering \& Entrepreneurial conduct.}

Mr. Amar has very good and educated friends circle. He was regularly receiving the support of finance and moral from his close good friends. They were giving new ideas to him for the business. He was doing the business of Motor-Cycle and other vehicles before started the bakery business. He decided to launch the business of food, as he was also not much success with the previous startups. For this, he was fortunate enough to get the help of family and friends.

Mr. Jai Prakash has stable relations with friends. They helped him in long range interpersonal communication. His friends, who have as of now doing similar business in different geographical locations, helped him when he had started the new venture. They helped him into make contact with various organizations to whom they were worked with.

Mr. Nanak is having a strong friendship with Mr. Kamal who is also in the same business, at the different geographical location. He motivates and inspires him to start his venture; he also helps Mr. Nanak to do the social networking which requires growing further.
In Mr. Sreeji's case, his one friend was having the franchise of the BreadLiner. So he took the help and advice of his friend. He started the small manufacturing unit of his own to bake the products under the guidance of his family and friend, which over a period turn into successful.

\section{Aggregate culture, individualistic culture \& Entrepreneurial conduct.}

Mr. Jai Prakash was born and brought up in the joint family, so he was quite familiar and adjusted with the aggregate culture. Mr. Jai Prakash has worked with his Cousins. He uplifts his knowledge to the level, enough to start the new venture and successfully to handle it. At present, he is working with a group of people including his relatives, and friends. In the meantime, he is administering and running the firm with quite an ease.

In the case of Mr. Nanak, there wins an aggregate culture than individualistic culture. Both siblings of Mr. Nanak help him to develop his business. They have decided the working hours per day, and as per market and the client request, they brought new ideas, new thoughts.

\section{Entrepreneurial training-education \& Entrepreneurial conduct.}

Entrepreneurial education lasts more grounded effect on Mr. Amar. His educational qualification is B.Com, MBA. He has four years of job experience. While working in various organizations, according to education, his training and working knowledge created an entrepreneurial goal which helped him to comprehend demand of the market. He connected proficient morals and increased quite a bit of trust from his customers, organizations which brought development of his business.

Mr. Shreeji completed his BBA and then undergoes his master degree in MBM. He also has 15 years of experience in the industry. With his training, working knowledge and management education, he decided to become an entrepreneur. This helps Mr. Sreeji to comprehend demand of the market, how to give satisfaction to the client and how to pick up trust and consideration of client. 
E. Culture \& Entrepreneurial conduct.

Mr. Amar very much connected to his culture, and his culture has an immense impact on him which can be visible in his work ethics and behavior. The experience of friends and family helped him to learn new lessons of business. He was a genuine risk-taker and keen to develop his business and expand it as well as family and friend's experiences helped him to learn. Mr. Amar was ready to take the risk. He implemented new thoughts-ideas for the development of his business.

Likewise, Mr. Amar, Mr. Sreeji also very much connected to his culture, and it has a great impact on his conduct as an entrepreneur. He has decided to start his career as an entrepreneur, and his family and friends supported his decision. They had also helped to grow in the decided field and offer every possible support which Mr. Sreeji needed.

Culture is having a more grounded effect on the aim of Mr. Jai Prakash's entrepreneurial conduct. Family's established business and entrepreneur friends inspired him to start his Venture. He brought new thoughts for the development of business as Standards and estimations of family, companions, and society helped him to break the convention ways and thinking patterns. He has solid idealness and understanding of society and culture.

In the case of Mr. Nanak's entrepreneurial conduct, culture has a more grounded effect. His associate culture firmly affects on his business goal and genuine supports through culture. As Mr. Nanak has favorability of the culture, family helped him in bringing new ideas and taking the risk on the venture. It also helped him to compete in the market and to get solutions to challenges in the development of the business. Due to the key factor like his family's culture and moral reinforcement, he was able to go for new thoughts and break the conventional barriers of culture.

\section{F. Unemployment \& Entrepreneurial conduct.}

Mr. Amar had MBA from VNSGU, Surat but he was unable to get the secure handsome salary in the job market. So, he decided to grow his own business to next level.
Mr. Jai Prakash had not taken any formal education or training, so he was also not ready to land a decent position, but rather his family base with business help him to do his own business.

Mr. Nanak had a just elementary study. He had not completed the college study, so he had no chance to get a proper job. He then chose to do agriculture because his father was landowners and farmer. In any case, later on, he liked to do business work than to do agriculture.

Mr. Sreeji had MBM from the University of Pune, Pune. He was doing a good job, but it was inconvenient for him due to geographical location. At his near local Bardoli, he could not get a job with high salary. So, instead of doing the job, he joins to his family business as his family was running the well-established business of bakery and cake shop from last 15 years.

\section{DISCUSSION}

The customary picture for entrepreneurship education that exhibits low academic citation and loose connections with learning theories. The connection of entrepreneurship with lifelong learning settings, vocational training, and career counseling is scarce in the literature. (Kakouris and Georgiadis, 2016) [14].

There was not an important factor in taking risks, which affected entrepreneurship intentions. Students lacked in essential resources to become entrepreneurs. Thus, it was understood that their risk-taking ability did not drive them towards entrepreneurship. (Wei-Loon Koe, 2016) [15].

Although, there is a positive attitude toward entrepreneurship, both the US and Turkish students have shown low levels of entrepreneurial intentions and the significant relationship among personality attributes of optimism, innovativeness, risk-taking propensity and entrepreneurial intention (Ozaralli and Rivenburgh, 2016)[17].

Personality factors (extrovert, neuroticism, agreements), support from family members and friends, parental profession, gender, entrepreneurship education, and access to finance have important positive effects [16].

Kumasi Polytechnic students' decision to graduate as entrepreneurs, while taking public comment about their decision had a significant 
negative impact on students [5].

\section{CONCLUSION}

Entrepreneurship helps to generate wealth and form capital in the country which ultimately contributes to the economic growth of the country. It filled the life of countryman with prosperity, and it helps to fight against poverty, unemployment and generate opportunities for the people. This study focuses on the social-cultural impact on the Entrepreneurship which is given below:

1. Culture, norms, values, directly and indirectly, help the entrepreneur to be a risk taker and implement new thoughts and ideas.

2. The family does affect the person to select the entrepreneurship as a career. Their moral and financial support means a lot to the budding entrepreneurs.

3. Friends and peers are also one source for a person to be an entrepreneur. Their skill knowledge, training, and contacts help him to grow as an entrepreneur.

4. Unemployment is also one strong reason, why people go for entrepreneurship and in this process, cultural and family also play a vital role in it.

5. Compare to individualistic culture, collective culture impact more on the entrepreneur to succeed in the venture.

6. Social Networking also one key factor for the entrepreneur. As more the more person is socially networked more competitive, he is in the market, as possible to compete healthily in demand of the market.

\section{RECOMMENDATIONS AND SUGGESTIONS}

Based on the findings of this study, the following recommendations are hereby made:

1. The government should form new, flexible policies and schemes to help the general population in setting up little and medium entrepreneurial ventures. So youth and investors can attract towards it.

2. The government should provide loans and financial, technical and start-up support to the young graduates.

3. The government should encourage compulsion to provide entrepreneur education.
Entrepreneurial development education should be included in syllabus from senior secondary school. It will help our youths to get knowledge and skills required for entrepreneurial development quite early, which ultimately impact on economic development.

4. Elders of the families, who have as of now been doing privately-run company, must scatter business thoughts among different individuals from the family through socialization. They also should impart their experiences to the next generation.

5. Those who are expert in the field should impart their experience, knowledge they gain with the needed friends and others.

\section{REFERENCES}

[1] Ali, Imran, Kayhan Tajddini, Kashif ur Rehman, Jawaria Fatima Ali, and Ishfaq Ahmed "University student's inclination of governance and its effects on entrepreneurial intentions: an empirical analysis", International Journal of Trade, Economics, and Finance, vol. 1, No. 1, pp.36, 2010.

[2] Jaén, Inmaculada, Francisco Liñán, A. Fayolle, P. Kyro, and F. Linan. "Cultural values in the study of a society's entrepreneurial potential", Developing, Shaping and Growing Entrepreneurship, pp. 154-180, 2015.

[3] Bruton, Garry D., David Ahlstrom, and Han-Lin Li. "Institutional theory and entrepreneurship: where are we now and where do we need to move in the future?", Entrepreneurship theory and practice, vol. 34, No. 3, pp. 421-440, 2010.

[4] Thornton, Patricia H., Domingo Ribeiro-Soriano, and David Urbano. "Socio-cultural factors and entrepreneurial activity: An overview", International small business journal, vol. 29, No. 2, pp. 105-118, 2011.

[5] Wongnaa, C. A., \& Seyram, A. Z. K. "Factors influencing Polytechnic students' decision to graduate as entrepreneurs”, Journal of Global Entrepreneurship Research, vol. 4, No. 1, pp. 1-13, 2014. 
[6] Lüthje, Christian, and Nikolaus Franke. "The 'making' of an entrepreneur: testing a model of entrepreneurial intent among engineering students at MIT", R\&D Management, vol. 33, No. 2, pp. 135-147, 2003.

[7] Sharma, Lalit, and Pankaj Madan. "Personality Traits Influencing Youth Entrepreneurship-An Empirical Study in Uttarakhand State, India", ISSN 2251-239X, pp. 6, 2013.

[8] Hayton JC, George G and Zahra SA, "National culture and entrepreneurship", A review of behavioral research. Entrepreneurship Theory and Practice, vol. 26, No. 4, pp. 33-52, 2002.

[9] Muhammad, I., Dali, M., Shah, N. R., Abdullah, M., Azman, A. R., Nordin, S. N., \& Nilai, B. B. "The Relationships between Parents' Background and Entrepreneurial Intention", International Muamalat and Entrepreneurship Conference, 2014.

[10]Jaskiewicz, Peter, James G. Combs, and Sabine B. Rau. "Entrepreneurial Legacy: Toward a theory of how some family firms nurture transgenerational entrepreneurship" Journal of Business Venturing, vol. 30, No. 1, pp. 29-49, 2015.

[11]Shirokova, Galina, Oleksiy Osiyevskyy, and Karina Bogatyreva. "Exploring the intention-behavior link in student entrepreneurship: Moderating effects of individual and environmental characteristics", European Management Journal, vol. 34, No. 4, pp. 386-399, 2016.

[12]Edelman, Linda F., Tatiana S. Manolova, Galina Shirokova, and Tatyana Tsukanova. "Student entrepreneurship in emerging markets: Can family help overcome the institutional voids?", In Academy of Management Proceedings, vol. 1, pp. 11966, 2016.

[13]Rani, S. H. B. A., and Tih Sio Hong. "Antecedents and consequences of entrepreneurial quality among graduate entrepreneurs", Asian Journal of Business and Management Sciences, vol. 2, No. 9, pp. 44-55, 2013.

[14]Kakouris, Alexandros, and Panagiotis Georgiadis. "Analysing entrepreneurship education: a bibliometric survey pattern", Journal of Global Entrepreneurship Research, vol. 6, No. 1, pp. 6, 2016.

[15]Koe, Wei-Loon. "The relationship between Individual Entrepreneurial Orientation (IEO) and entrepreneurial intention", Journal of Global Entrepreneurship Research, vol. 6, No. 1, pp. 13, 2016.

[16]Wongnaa, Camillus Abawiera, and Anthony $\mathrm{Zu}$ Kwame Seyram. "Factors influencing Polytechnic students' decision to graduate as entrepreneurs", Journal of Global Entrepreneurship Research, vol. 4, No. 1, pp. 2, 2014.

[17]Ozaralli, Nurdan, and Nancy K. Rivenburgh. "Entrepreneurial intention: antecedents to entrepreneurial behavior in the USA and Turkey", Journal of Global Entrepreneurship Research, vol. 6, No. 1, pp. 3, 2016.

[18]Akhter, Rahma, and Farhana Rahman Sumi. "Socio-cultural factors influencing entrepreneurial activities: A study on Bangladesh”, IOSR Journal of Business and Management, vol.16, No.9, pp. 01-10, 2014. 